\title{
Allocation of potential value socio-ecology post tin mining Kolong in Bangka Island
}

\author{
Wahyudi Himawan ${ }^{1,2, *}$, Fachrurrojie Sjarkowie ${ }^{3}$, Indra Yustian ${ }^{4}$, and Ardiyan Saptawan ${ }^{5}$ \\ ${ }^{1}$ Doctor Programs of Environmental Study Postgraduate University of Sriwijaya, 30139 Palembang, Indonesia, \\ ${ }^{2}$ Education and Training Department of Bangka Belitung Province, Indonesia \\ ${ }^{3}$ Deptartment of Agribusiness Faculty of Agriculture, University of Sriwijaya, 30662 Inderalaya, Indonesia \\ ${ }^{4}$ Deptartment of Biology Faculty of Mathematics and Natural Sciences, University of Sriwijaya, 30662 Inderalaya, \\ Indonesia \\ ${ }^{5}$ Deptartment of Public Administration Faculty of Social \& Politics, University of Sriwijaya, 30662 Inderalaya, \\ Indonesia
}

\begin{abstract}
Kolong is a water basin as an impact of post tin mining in Bangka Island. Kolong should be managed properly to minimize some impacts, improve the quality of socio-ecological, and the income of local citizen. The purpose of this study was to analyze the potential allocation of socio-ecology value of the post tin mining. The case studies are Kolong in the Central Bangka Regency. This research was used resources valuation methodology, $\mathrm{ABAD}$ model classification, and observations. To determine the relationship of social ecology of the Kolong using SEM WarpPLS. The result shows that revenue of economic value of kolong in Bangka Island is IDR 17.9 Billion/year from utilization of Water Supply System, raw water and aquaculture. The diversity Kolong utilization as production tool of social needed in Bangka Island are $6 \%$ as Water Supply System, $9 \%$ as aquaculture, $0.2 \%$ as tourism, and almost $84.8 \%$ unused and owned by local government and private companies. The changing of kolong system influence the changing of social systems. The social variables that are most affected are the technology and local population. Utilization of Kolong as the economic value depends on its classification which based on the ABAD model.
\end{abstract}

\section{Introduction}

Exploration and exploitation activities of tin ore inBangka Island had big impact to physical change, spatial structure, social, and environment use. Its social impact should not be underestimated, the interaction between mining industry and the citizen could cause various of social problems, economic, culture, and public policy. The economic wellbeing enhancement is the hope of local citizen from mining industry in their area [1].

Exploration and exploitation tin ore in Bangka Island had left a post mining area which is flooded and called Kolong. Kolong's management not only related to environment aspects and economic, but also social, politics, and public policy [2]. The environment restoration that has been done through partial ecologictechnical approach gradually lost its legitimacy and interest $[3,4]$. Kolongs that was spread around Bangka have a big potential to be managed and used for citizen well-being and regional development. Regional government has tried to develop post mining area with various functions $[5,6]$. These functions are for tourist attraction, community economic production facilities, raw water source, new settlement area, etc to preserve and optimize economics value, and post mining area ecologists.
For planning and implementing those policies, it is important to know and valuate economics and socioecology values. Valuation of potential value is used for classification and allocating Kolong of post mining potential utilization. The value of economic potential allocation and socio-ecology are used to make a strategy of management policy and Kolong of post mining utilization. The focus of research on Central Bangka Regency is believed to represents the conditions and characteristics of kolong on Bangka Island. The purposes of this research are to do economic valuations of kolong's utilization, socio-ecology valuations of utilization and management of Kolong, classify Kolong of post mining on Bangka Island and counts economic potential allocation, social, and ecology of Kolong on Bangka Island.

The aims of this study:

1. Conducting economic valuation and socio-ecological utilization of Kolong;

2. Classify the post tin mining of Kolong in Bangka Island;

3. Calculating the allocation of the potential economic, social, and ecological of the Kolong on Bangka Island.

\footnotetext{
* Corresponding author: wahyudi.himawanbabel@gmail.com
} 


\section{Methodology}

\subsection{Economic Valuation}

Valuation method was used based on Ministry of Environment Regulation Number 15 year 2012. The total economics value reflects monetary value which is produced by ecosystem function of Kolong, both extractive and non-extractive, calculated by:

$\mathrm{TEV}=$ Use Value + Option Value

$$
\mathrm{TEV}=[(\mathrm{DUV}+\mathrm{IUV})+(\mathrm{OV}+\mathrm{QOV}+\mathrm{BV}+\mathrm{EV})]
$$

Where :

$\begin{array}{ll}\text { TEV } & : \text { Total economic value } \\ \text { DUV } & \text { : Direct use value } \\ \text { IUV } & : \text { Indirect use value } \\ \text { OV } & : \text { Option value } \\ \text { QOV } & : \text { Quasi option value } \\ \text { BV } & : \text { Bequest value } \\ \text { EV } & : \text { Existence value }\end{array}$

The productive effort of Kolong resource utilization was counted by unit rate calculation, market rate minus production cost minus proper profit, formula is given by:

$$
\mathrm{UR}=(\mathrm{MR}-\mathrm{APC})-\mathrm{PPIR}
$$

where:

UR : Unit rent

MR : Market rate

APC : Average production cost

PPIR : Proper profit as investment retribution

\subsection{Classification of Kolong}

Classification of kolong was done by ABAD (Access, Broad, Age, and Depth) model as shown in Table 1 and Table 2.

Table 1. Classification criteria according to social economic perspective

\begin{tabular}{|l|c|c|c|c|}
\hline No & Access (km) & Broad (ha) & Age (year) & Depth (m) \\
\hline \multirow{2}{*}{1} & Good & Wide & Old & Deep \\
& $<0.5$ & $4>$ & $20>$ & $5>$ \\
\hline \multirow{2}{*}{2} & Fair & Fair & Fair & Fair \\
& $0.5-1$ & $1-4$ & $5-20$ & $2-5$ \\
\hline \multirow{2}{*}{3} & Bad & Narrow & Young & $\begin{array}{c}\text { Superficial } \\
\end{array}$ \\
& $>1$ & $<1$ & $<5$ & $<2$ \\
\hline
\end{tabular}

Table 2. ABAD model classification

\begin{tabular}{|c|l|c|c|c|}
\hline \multirow{2}{*}{ No } & \multirow{2}{*}{ Classification base } & \multicolumn{3}{|c|}{ Value } \\
\cline { 3 - 5 } & & Low & Fair & High \\
\hline 1 & Access & $\mathrm{A}_{1}$ & $\mathrm{~A}_{2}$ & $\mathrm{~A}_{3}$ \\
\hline 2 & Broad & $\mathrm{L}_{1}$ & $\mathrm{~L}_{2}$ & $\mathrm{~L}_{3}$ \\
\hline 3 & Age & $\mathrm{U}_{1}$ & $\mathrm{U}_{2}$ & $\mathrm{U}_{3}$ \\
\hline 4 & Depth & $\mathrm{K}_{1}$ & $\mathrm{~K}_{2}$ & $\mathrm{~K}_{3}$ \\
\hline
\end{tabular}

where's 1: low, 2: fair, and 3: high

\subsection{Socio-ecology allocation}

Socio-ecology potential allocation methodology is summing all of benefits and function of Kolong either extractive or non-extractive. Socio-ecology analysis was done by using five fundamentals in ecology, i.e: (1) interaction, (2) interdependency, (3) diversity, (4) harmonization, and (5) sustainability [7,8,9]. To determine the variables in the social system both formative and reflective, use Structural Equation Modelling Analysis with SEM Warp PLS Program [10].

\section{Results and discussion}

\subsection{Economic allocation}

Based on the identification and inventory by doing a closed area map overlay, IUP (mining permit) map, administration map, PIPIB moratorium map, and Central Bangka local government year 2011-2013, where has 227.991 ha area, is known:

- Mining permit (IUP)

- IUP with expired permit up to 2015

- Area that becomes Kolong

- Number of identified Kolong

- Number of inventoried Kolong

- Assumed water volume

- Potential allocation

Based on ABAD model classification, among 276 of inventoried kolong, there are 27 pcs for first class or $10 \%, 193$ pcs for second class or $70 \%$ and 56 pcs for third class or $20 \%$. As shown in the map Fig.1 below:

\subsection{Classification of kolong}

Based on NEA(the economic value of water) Study, Optimum water allocation for PDAM (local water company) and BBI(fish breeding centers) Sungailiat, in such condition that the sums of water economic value of Kolong Dam-3 Pemali for each corresponding 1.36 Billion/Year [11]. Based on ABAD model classification, among 276 of inventoried Kolong at Central Bangka Regency, there are $27 \mathrm{pcs}$ for first class or $10 \%, 193 \mathrm{pcs}$ for second class or $70 \%$ and 56 pcs for third class or $20 \%$, after economic value was done, both of extractive or non-extractive. Regarding to this valuation, economic value of kolong on Bangka, calculated by the equation (1) and (2) was IDR 9.5 billion/year for Water Supply System utilization and fish cultivation, and IDR. 17.9 billion/year for the Kolong itself. 


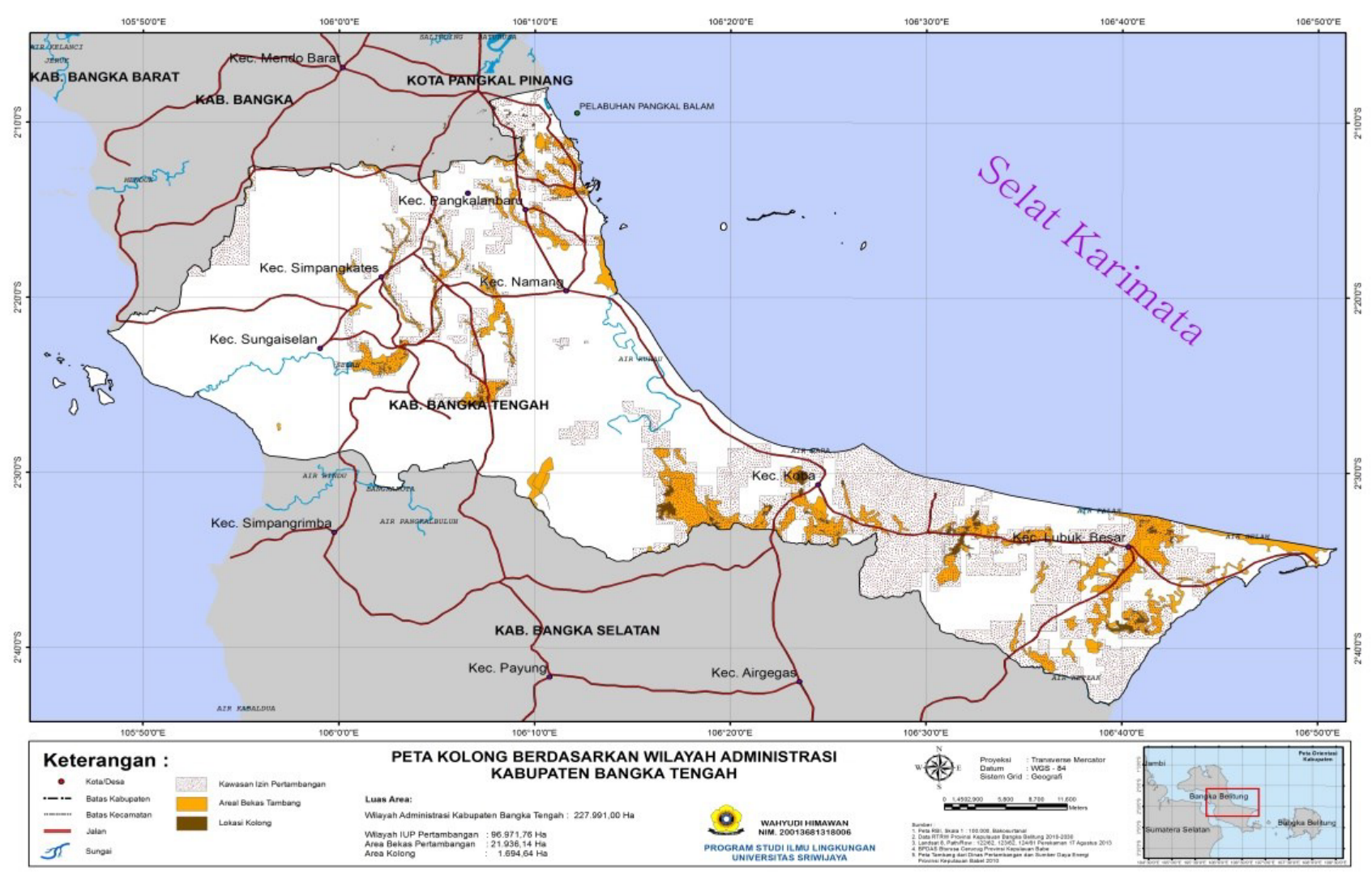

Fig.1. Map of Kolongs in Central Bangka Regency

\subsection{Socio-ecology allocation}

According to the perception of stakeholders, the utilization type of Kolong, the type of tourism utilization from of a tourist village and artificial edutourism [5]. In this research, according to the perception of stakeholders, the utilization types of Kolong were as Water supply system, raw water for citizen, local asset, community settlement, and water resource for agriculture and industry. The reflective analysis of SEM WarpPLS as shown in Figure 2.

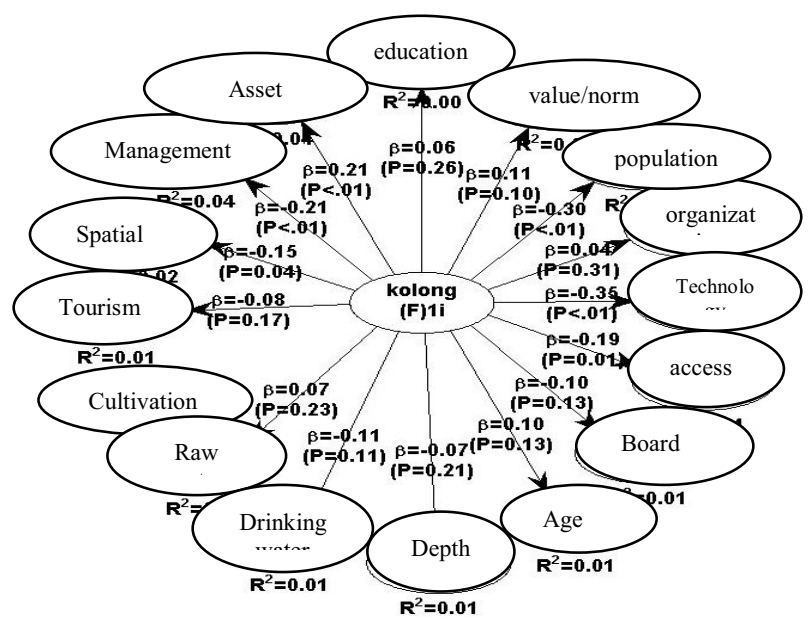

Table 3. Reflective analysis of kolong's socio-ecology

\begin{tabular}{|c|c|c|c|c|}
\hline \multirow{2}{*}{ No } & \multirow{2}{*}{ Component } & \multicolumn{2}{|c|}{ Formative } & \multirow{2}{*}{$\begin{array}{c}\text { Coefficient } \\
\beta r^{2}\end{array}$} \\
\hline & & $\beta r$ & $\mathbf{P}_{\mathbf{r}}$ & \\
\hline \multicolumn{5}{|c|}{ Social } \\
\hline 1. & Education & 0.060 & 0,20 & 0,49 \\
\hline 2. & Value/Norm & 0.110 & 0,49 & 0,36 \\
\hline 3. & Population & 0.300 & 0,37 & 0,09 \\
\hline 4. & Organization & 0.040 & $<0,01$ & 9,00 \\
\hline 5. & Technology & 0.350 & $<0,01$ & 12,25 \\
\hline & Influence & 0.860 & & 88,36 \\
\hline \multicolumn{5}{|c|}{ Potential } \\
\hline 1. & Access & 0.190 & 0.010 & 3.610 \\
\hline 2. & Broad & 0.100 & 0.120 & 1.000 \\
\hline 3. & Age & 0.100 & 0.130 & 1.000 \\
\hline 4. & Depth & 0.070 & 0.210 & 0.490 \\
\hline & Influence & 0.460 & & 21.160 \\
\hline \multicolumn{5}{|c|}{ Economic use } \\
\hline 1. & Drinking Water & 0.110 & 0.11 & 1.210 \\
\hline 2. & Raw Water & 0.070 & 0.23 & 0.490 \\
\hline 3. & Cultivation & 0.110 & 0.10 & 1.210 \\
\hline 4. & Tourism & 0.080 & 0.17 & 0.640 \\
\hline & Influence & 0.370 & & 13.690 \\
\hline \multicolumn{5}{|c|}{ Policy } \\
\hline 1. & Spatial & 0.150 & 0.04 & 0.006 \\
\hline 2. & Management & 0.210 & 0.01 & 0.002 \\
\hline 3. & Asset & 0.210 & 0.01 & 0.002 \\
\hline & Influence & 0.570 & & 32.490 \\
\hline
\end{tabular}

Fig. 2. Analysis kolong reflective contsruct 


\subsubsection{Socio-ecologi fungtion}

Based on the reflective analysis of SEM WarpPLS generated that Kolong system changes significantly influence $88.6 \%$ to changes the social system, as shown in Tabel 3. While based on the analysis of the construct of formative changes in the social system has no significant effect on the changes of kolong.

The social systems component which influenced by the kolong's changing can be observed in reflective analysis as shown in Fig. 3 below.

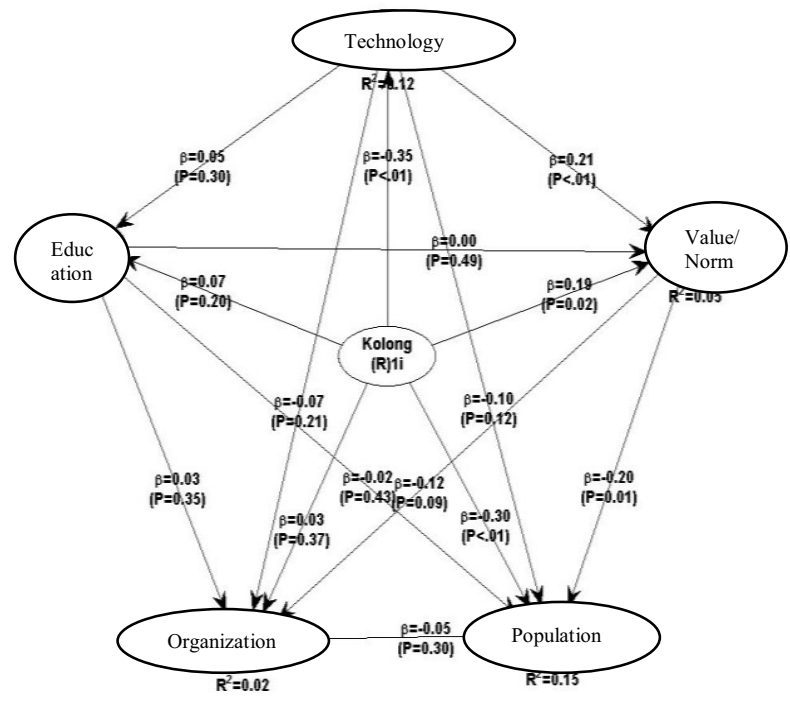

Fig. 3. Social component influenced convertion used of Kolong.

From the analysis above, the function kolong the assumption of the general equation is:

$$
\mathrm{K}=f(\mathrm{aS}+\mathrm{bP}+\mathrm{cK}+\mathrm{dE})
$$

From the reflective analysis result above, the equation (1) can be simplified as follows:

Where:

$$
\mathrm{K}_{\mathrm{r}}=f(\mathrm{aS}+\mathrm{bP})
$$

$\mathrm{Kr}$ : Reflective kolong (Kolong effect on external valuable change)

a : Coefficient on social influent

b : Coefficient on potential influent

5. Sustainability Kolong's utilization will happen if Kolong's ownership status and economic value have various benefit in economic, social, and environment (Class I and Class II based on ABAD Model).

6. The Construction Strategy of Socio-ecology must consider several factors as follows; Stability(sociopsychology), Eficiency (socio-ecology), Productivity (socio-economic) and Sustainability (socioculture)[12]. c : Coefficient on influent of policy

d : Coefficient on influent of economic use

S : Social variable

$\mathrm{P} \quad$ : potential variable

$\mathrm{K}$ : Variable of policy

E : Variable of economic use

It can be concluded that changes in the Kolong for the management and utilization has very significant effect $(88.36 \%)$ on the social variables. So that the model equations that apply are:

$$
\mathrm{Kr}=f(a S)
$$

Based on the equation (4) above means that: technology and local population in communities are influenced by kolong utilization changes fungtion. Components of the social system variables reflective affected by the changes of kolong system based on the relationship rows are: technology, organizations.

\subsubsection{Ecological principle analysis}

Based on ecological principles, it can be explained as follows:

1. Interaction has occured between social system and environment system for utilization of Kolong. The social utilization system has a format that fit to environment system by using local knowledge and technology from citizen to use Kolong as an economic production tools.

2. Interdependency between social system and environment of Kolong has occured with an adaptation format of social system which fit to environment system.

3. Diversity of Kolong utilization as socio-ecology value were classified and used to Water Supply System and raw water for citizen, aquaculture and recreation. Class II of Kolong was used as water source for industry and agriculture. In that, Kolong's class III was left as it was because a Kolong can only be used for economic production activities after 5-10 years.

4. Harmonization The key of harmonization of socioecology system are ownership asset and technology control.

\section{Conclusion and suggestion}

Based on the results and discussions, it can be concluded that:

1. Potential allocation of the economic value of Kolong in Bangka Island is IDR 17,9 billion/ year.

2. Potential allocation of the socio-ecology benefit value has various allocations utilization and management as:
a. Water supply system
b. Raw water for citizen
c. Local assets 
d. Community settlement

e. Tourism

f. Water source for agriculture and industry

3. The main factor as an indicator for utilization and management of Kolong, based on socio-ecology perspective, are ownership assets, technology controls, and Kolong's management as a production source.

4. Adaptation process of social system is balance to ecosystem change pattern of Kolong.

\section{References}

1. S. Sujitno, Dampak Kehadiran Timah Indonesia Sepanjang Sejarah. PT. Timah, Jakarta (2010)

2. Bapedalda Provinsi Kepulauan Bangka Belitung. Kondisi Kerusakan Lingkungan Hidup di Provinsi Kepulauan Bangka Belitung. (2007)

3. F.H. Buttel., R C. Humphrey. Sociological Theory and the Natural Environment. pp. 33-69 in Handbook of Environmental Sociology edited by R.E. Dunlap and W. Michelson., C.T. Westport.
Greenwood Press (2002)

4. F.H .Buttel Ecological Modernization as Social Theory. Pergamon Journal Madison. USA. (2000)

5. C. Henny.. "KOLONG" Bekas Tambang Timah di Pulau Bangka: Permasalahan Kualitas Air dan Alternatif Solusi Untuk Pemanfaatanya, JOLI 37(1): 119-138 ISSN 0125-9830. (2011)

6. L. Meyana, M. Sudadi, B. Tjahjono.. JPSL. 5(1) 51-60 : 20086-4639 (2015)

7. O. Sumarwoto, Ekologi Lingkungan Hidup dan Pembangunan ISBN 979-428-285-5 (1997)

8. E.P. Odum, Basic Ecology (1983)

9. G.T. Miller, Living in the Environment: Principle, Connection, and Solution (2006)

10. M. Sholihin, D. Ratmono, Analisis SEM-PLS dengan WarpPLS, ISBN 978-979-29-4267-5 (2013)

11. F. Sabri, Nilai Ekonomi Air Kolong DAM-3 Pemali, Gadjah Mada University, Yogyakarta (2008)

12. F. Sjarkowie, Agro Ekosistem Lahan Basah Lestari. Palembang (2014) 